\title{
APBA2 Gene
}

National Cancer Institute

\section{Source}

National Cancer Institute. APBA2 Gene. NCI Thesaurus. Code C104843.

This gene plays a role in neuronal transport. 